\title{
The Old Wind Still Blows. Wind Energy: Solution To The Paradox Of The Entrepreneur?
}

Flory Anette Dieck-Assad, ITESM-Campus Monterrey, Mexico

\begin{abstract}
In 2009, Mexican President Felipe Calderon announced his commitment to the world to reduce $50 \%$ of greenhouse gas emissions by the year 2050. As a strategy he set a goal of 35\% of electricity generation from clean energy by the year 2024. On September 29, 2010, the President shared his concern about the paradox he observed in Mexican businessmen when he participated in the Energy Efficiency and Access Forum convened by the Mexican Ministry of Energy (SENER) where experts from 40 countries were present. On one hand entrepreneurs want to receive financial support for all areas damaged by natural disasters (hurricanes) caused by climate change, and on the other hand they criticize the commitments on behalf of Mexico to reduce greenhouse gas emissions by the year 2050, arguing that they need to continue emitting carbon dioxide in order for its industries to continue earning money. Annoyed about this paradox, the President asks himself, "Would wind energy be an economically viable solution to meet the environmental commitments of Mexico with the world without negatively affecting the financial statements of private companies so that they remain profitable and continue generating jobs?" Is there a solution to the dilemma: profit vs. clean energy?
\end{abstract}

Keywords: Profit; Wind Energy; Clean Energy; Greenhouse Gas Emissions

\section{INTRODUCTION}

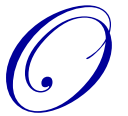

n September 29, 2010, the Energy Efficiency and Access Forum, convened by the Mexican Ministry of Energy (SENER), was held in Mexico. Experts from 40 countries attended this event as well as prominent Mexican businessmen and international personalities such as the UN General Director for Industrial Development, Kandeh Yumkella, the World Bank Director of the Department of Sustainable Development in Latin America and the Caribbean, Laura Tuck, the Managing Director of the World Economic Forum, Richard Samans, and the Inter-American Development Bank Vice President for Private Sector and Operations without Guaranteed Sovereignty, Steven Puig.

López (2010) stated that Mexican President Felipe Calderon shocked the audience when he said: "It was a very significant paradox for me...(that), while I was meeting with high-ranking leaders of the business community of Mexico...the same people who asked for the Federal Government's urgent help to reconstruct the states affected by natural disasters, argued why did Mexico accept emission reduction commitments if they needed to continue emitting carbon dioxide in order for their industries to continue earning more money."

After a brief pause, the President continued saying: "I tell entrepreneurs: Hey, the cause of heavy rains is climate change. The solution is to fight climate change by reducing greenhouse gas emissions." President Felipe Calderon thought to himself: - "I admit that I went ahead and in 2009 announced my engagement with the world to reduce 50\% of greenhouse gas emissions in Mexico by the year 2050. Did I possibly rush into establishing this important commitment with the world?" 


\section{WIND ENERGY IN MEXICO}

Undoubtedly, the commitment of the President of Mexico to the world is remarkable. He established a specific goal of $35 \%$ of clean energy electricity generation by the year 2024. According to the targets set by the SENER (2010) in its National Energy Strategy (NES), they should develop 88,000 megawatts of electricity generation for the year 2024 that will consist of $35 \%$ renewable energies, as seen in Table 1:

\begin{tabular}{|c|c|}
\hline \multicolumn{2}{|c|}{$\begin{array}{c}\text { Development Goals for Electricity Generation Capacity in Mexico } \\
\text { by the year } 2024\end{array}$} \\
\hline$\underline{\text { Megawatts }}$ & Characteristics \\
\hline 15,000 & New and existing Hydroelectric Projects \\
\hline 3,500 & Private Projects agreed upon in 2010 \\
\hline 1,000 & Geothermic Projects \\
\hline 1,000 & Nuclear Projects \\
\hline$\underline{9,500-10,000}$ & Development of Private Projects \\
\hline $\mathbf{3 0 , 0 0 0}$ & Clean energy to be installed by the year 2024 \\
\hline
\end{tabular}

Source: CRE (Mexican Energy Regulatory Commission, 2010) megawatts.

The government goals deal with the possibility of private development projects between 9,500 and 10,000

Which would be the conditions under which the private sector would willingly collaborate on these projects?, President Felipe Calderon thought.

During lunch, President Felipe Calderon spoke with the Director of the Advisors of his Presidency: - The issue of carbon dioxide emissions has been debated in the past between industrial companies, he said with a tone of bewilderment.

I have considered wind energy as a clean energy alternative to meet the commitments of Mexico with the world, but I am worried that this could cause a significant increase on business costs and have some kind of social impact. The President continued with great seriousness: - For this reason, I ask you to conduct a profound research to justify if wind energy could be defended, not only as a clean energy, but also as a low cost alternative for Mexico.

He said with great sensitivity: - I would like to be prepared in order to fairly discuss this issue with Mexican entrepreneurs to whom I am very grateful for being job generators in Mexico.

\section{WIND ENERGY MAP IN MEXICO: THE DIFFICULTY OF ITS COSTS}

The Director of the Mexican Presidential Advisors leafed through the latest report of the International Energy Agency-IEA (2010) identifying frightening projections for Mexico: if the current pace of production and consumption remains constant, the proven oil reserves of Mexico will last for only nine years, while the natural gas reserves will only last for 8 more years, considering the country's energy demand.

Mexico is definitely heading towards an energy crisis and the government should take a greater involvement and leadership in this regard, concluded the Director of the President's Advisory Team. He seriously continued: Now I understand, more than ever, the gravity of the analysis that the President requested me to evaluate and the role my report and comments will play for the future of my country.

The Director of the Mexican Presidential Advisors decided to seek out experts in this field to conduct a survey on the feasibility of electricity production via wind energy. According to the Undersecretary of Electricity 
within the SENER (2010), the effective capacity of wind energy electricity generation increased from 2.2 megawatts in 2006 to 85.5 megawatts in 2007. But it stagnated at 85.3 megawatts from 2008-2010. The participation of effective capacity of wind energy electricity generation from the total energy for these means increased from $0.00044 \%$ in 2006 to $0.1626 \%$ in 2010, including a period of practical stagnation during 2007-2010 (Chazan, 2010).

Francisco Fernandez-Castillo, Director of C-Strategy, addressed the Mexican President's Advisory Team saying: Mexico is one of the most profitable countries to generate wind energy in the world. It has the potential to install 44,180 megawatts only in the states of Oaxaca and Tamaulipas.

With great passion in his voice, he continues stating: The results of our research show that states like Oaxaca, Tamaulipas, Chihuahua, and Baja California are most benefited by winds (Table 2). However, the wind potential in Mexico is underutilized.

\begin{tabular}{lc}
\hline \multicolumn{2}{c}{ Table 2 } \\
Wind Potential in Mexico by states \\
\hline Mexican States & Potential in Megawatts (MW) \\
\hline Oaxaca & 28,400 \\
Tamaulipas & 15,780 \\
Baja California & 11,050 \\
Chihuahua & 11,050 \\
Chiapas & 9,470 \\
Nuevo Leon & 7,890 \\
Veracruz & 7,890 \\
Quintana Roo & 6,620 \\
Yucatan & 6,000 \\
& Total \\
\hline
\end{tabular}

Source: Developed on November 2010 by C-Estrategia for the Mexican Institute for Competitiveness (IMCO), according to the geographical map which identifies the states with higher winds, to estimate the maximum installed potential of wind energy in Mexico.

Francisco Fernandez-Castillo further explains: By the year 2010, Mexico has barely developed 170 megawatts of wind generation capacity, which is mainly concentrated in the state of Oaxaca. Surprisingly, this represents only $0.38 \%$ of the wind potential of Oaxaca and Tamaulipas, and only $0.16 \%$ of the total installable wind potential in Mexico.

The Director of the Mexican Presidential Advisors commented: It is important to consider the aspect of competitiveness of prices in the electricity industry (Keel, Kilk, \& Valdma, 2009). The price of electricity in the industrial sector for Texas, U.S.A. was 5.33 U.S. cents per kilowatt-hour in 2003, while in the city of Monterrey, Mexico it was 5.98 U.S. cents per kilowatt-hour, and in Mexico City it was 6.49 U.S. cents per kilowatt-hour. Thus, on average in 2003, the prices were approximately $17 \%$ higher in Mexico than in the U.S.A. The Energy Information Administration (2010) specifies that in the year 2010, medium and large companies established in Mexico are already paying an average of $20 \%$ more for their electricity bills compared with the U.S.A. Energy prices impact the competitiveness of companies, so they should look for the cheapest energy prices in order to reduce the price gap with U.S.A. After this valuable insight, he questioned: How will wind energy make electricity rates in Mexico more competitive?

For this reason, he thought that the main incentive for the installation of wind farms in Mexico is strictly economic. If we estimate that the cost of electricity for medium and large industries in 2010 was 10.32 cents per kilowatt-hour, while the price at which a business using wind energy is profitable is 6.20 cents per kilowatt-hour, then this differential becomes an attractive incentive for those interested in developing this type of energy. 
The unit costs of electricity generation per energy technology, according to the National Energy Strategy (NES) published by SENER (2010), show the advantages of wind energy production and are presented in Table 3.

If we consider the savings in electricity bills for the industry, and also the possibility to generate Carbon Credits that can be sold in the stock market, there are even greater advantages, thought the Director of the Presidential Advisors. By not relying solely on fossil fuels, wind farms can contribute to reduce greenhouse gases. In fact, by the year 2010, five wind projects are already registered with the Clean Development Mechanism established by the Kyoto Protocol which allows the emission and trade of Carbon Credits. Three other wind farms are in the process of being registered. The development of all these projects could lead to the emission of more than 10 million Carbon Credits, whose price could exceed 85 million euros per year.

\begin{tabular}{|c|c|c|c|c|c|}
\hline \multicolumn{6}{|c|}{$\begin{array}{c}\text { Unit Costs in Dollars of } 2009 \\
\text { (exchange rate } \$ 14.5 \text { Mexican Pesos per Dollar) }\end{array}$} \\
\hline Energy Type & $\begin{array}{c}\text { Investment } \\
\text { USD/k W } \\
\text { (construction \& } \\
\text { management) } \\
\end{array}$ & $\begin{array}{c}\text { Operation Cost } \\
\text { USD/MWh } \\
\text { (fuels, operation } \\
\text { and maintenance) }\end{array}$ & $\begin{array}{c}\text { Leveled Cost } \\
\text { USD/MWh } \\
\text { (investment \& } \\
\text { operation) } \\
\end{array}$ & $\begin{array}{c}\text { Greenhouse Gas } \\
\text { Emissions } \\
\text { Ton } \mathrm{CO}_{2} \text { eq/MWh }\end{array}$ & $\begin{array}{c}\text { Construction Time } \\
\text { (years) }\end{array}$ \\
\hline Combined Cycle (gas) & 973 & 58 & 74 & 0.40 & 2.50 \\
\hline Hydroelectric & $2,000-2,500$ & 4 & $76-116$ & ----- & $4.00-6.00$ \\
\hline Carboelectric & 2,323 & 41 & 80 & 0.80 & 3.50 \\
\hline Geothermoelectric & 2,169 & 48 & 82 & ----- & 2.25 \\
\hline Nucleoelectric & 5,000 & 19 & 84 & ---- & 8.00 \\
\hline Wind electric energy & 2,360 & 13 & 110 & ---- & 1.00 \\
\hline Turbogas & 650 & 86 & 152 & 0.70 & 1.00 \\
\hline
\end{tabular}

Source: SENER (2010)

However, the Mexican federal electricity commission, Comisión Federal de Electricidad - CFE (2010) states that the cost of wind projects hinders their expansion. Indeed, the Project Development Program of the Electricity Sector (POISE—Programa de Obras del Sector Electrico in Spanish) 2010-2024, states the following: "To incorporate wind energy into the expansion plans of the electricity sector in Mexico, economic incentives are needed to offset the difference in costs between more competitive technologies, or have energy policy guidelines that allow its incorporation in these expansion plans."

If wind energy plants are compared against combined cycle plants using natural gas as fuel, or coal-fired plants, wind energy plants are more expensive, even if they incorporate the economic value of the decrease of greenhouse gas emissions into the atmosphere (Galbraith, 2009).

The law of public service of electricity (Ley de Servicio Publico de la Energia Electrica) in Mexico requires the CFE to develop inexpensive electricity generation projects. The CFE must analyze the most competitive electricity generation options. Fiscal and economic incentives have supported the development of wind energy projects in Europe, being Germany and Spain the countries with the highest installed capacity. From the POISE analysis it is concluded that without any financial support wind farms would only be viable when natural gas prices are higher than the 9 dollars per million BTUs; and in 2010 this price was 4.5 dollars.

\section{THE OLD WIND STILL BLOWS}

Before proceeding with the investigation, the Director of the Mexican Presidential Advisors decided to pause and get acquainted with the concept of wind energy. No doubt, the old wind still blows to meet the world's energy needs. Thus, the Director of the Mexican Presidential Advisors, focused on a technical study (Makkawi, Celik, \& Muneer, 2009) to learn more about this new way of generating energy, although it is the oldest in the world. 
Wind energy is generated by wind. Turbines are used to transform the wind's kinetic energy, when connected to a generator to produce electricity. Wind turbines convert the wind's kinetic energy into electricity by means of blades or propellers called aero generators or windmills, which rotate a central shaft that is connected, through a series of gears (transmission), to an electric generator. To take advantage of wind energy is important to know the diurnal, nocturnal, and seasonal wind variations, because this type of energy requires wind to reach a minimum speed of $12 \mathrm{~km} / \mathrm{hr}$., but not to exceed $65 \mathrm{~km} / \mathrm{hr}$.

Since the 90's, wind technology has advanced both in energy generation capacity and in cost. While in 1997 the average turbine produced between 600 and 750 kilowatts, by 2010 there were turbines producing up to 7 megawatts. The largest turbines are intended for offshore wind farms (Byrne \& Houlsby, 2003). It is estimated that the cost of a wind turbine is about $\$ 1,700$ dollars per kilowatt, but the cost of generated electricity depends on the wind speed and its distribution throughout the year. The SENER estimates that, under optimal conditions, the cost of wind electricity is 5 U.S. cents per kilowatt hour, resulting to be a competitive technology in the market.

The tower that supports the horizontal axis of the wind turbine is important because wind power is a function of the cube (third power) of the wind speed and wind blows stronger as the distance is farther away from the ground. Hence, the rotor shaft is positioned at least 10 meters from the ground in small wind turbines and up to 50 or 60 meters above the ground in 1000-kw machinery. In a 500-kw wind turbine, the towers are typically 40 meters high and can be of two types: tubular, recommended in coastal areas, wetlands and salt pans, and structural or reticular (lattice), characteristic of dry regions with little air pollution and considered cheaper and easier to lift.

The competitive advantages of wind energy over other options are:

1. It reduces dependency on fossil fuels.

2. The levels of pollutant emissions associated with fossil fuel consumption are reduced in comparison with those generated with wind energy.

3. Wind energy technologies are better developed to compete with other energy generating sources.

4. The construction time is less compared with other energy options.

5. Being modular plants, they are convenient when it requires rapid growth response time.

China and India are two countries that have decided to trigger this form of electricity generation, for which they have associated with European companies to manufacture the required equipment.

In Mexico, the development of the technology of converting wind energy to electricity, began with a wind energy efficiency program from the Electrical Research Institute (IIE-Instituto de Investigaciones Eléctricas in Spanish) in February 1977, when the General Operations Manager of CFE, granted to IIE the Wind Energy Electrical Experimental Station known as "El Gavillero", near an ejido (community-owned land) in Huichapan, Hidalgo. The aim was to produce wind energy for the already electrified ejido using a micro wind plant comprised by two Australian aero generators Dunlite of $2-\mathrm{kw}$ each, a battery bank, and a $6-\mathrm{kw}$ inverter to feed the power network distribution of the ejido (Rosenthal, 2010). The inverter, built by CFE personnel, failed to work above the 2-kw demand point due to component quality problems; so the actual experiment could not be completed. However, since the site was technologically ready for implementation, the average hourly speed wind statistics were available, and knowing the response characteristics of the aero generators, it was possible to numerically estimate the possible energy supply for the ejido. The wind cycle of the site produced excess energy during the summer and had a deficit over the winter for the normal consumption of the ejido. The station "El Gavillero" remained in operation until 1996 when it was dismantled.

This event shows the limitations of this type of renewable energy: they are subject to production variability depending on the weather, which compels the design of energy reservoirs to avoid these production variations. Another limitation is that its potential is very different depending on the geographical region in question.

A wind energy project is profitable depending on its development costs, the initial investment required, and the calculation of the cost per unit of energy produced. 
In 1994, in the region called "La Ventosa" in the Mexican state of Oaxaca, wind-powered electricity plant consisting of 7 aero generators began operations. The CFE considered this region to be one of the windiest places of the Isthmus of Tehuantepec. This wind mini plant represents the first experience of the CFE with the interconnection of wind power to the national grid.

The lack of infrastructure to transmit electricity into the national grid is hampering the development of private wind farms. The problem is that there is insufficient transmission capacity from the wind farm construction point to the national grid, and in the case when electricity consumption is not at the production point, transmission lines are required. While this is not resolved, wind projects cannot be implemented. Although the CFE is not responsible for creating specific infrastructure for private businesses, the CFE is already planning to build new transmission lines.

Francisco Salazar, President of the Mexican Energy Regulatory Commission (CRE) said that under strictly economic criteria, renewable energies are more expensive compared to those generated by fossil fuels (Revkin, 2006). Forcing the CFE to purchase electricity from private wind farms to distribute it in the domestic market, would cause the CFE's electricity cost to increase between $10 \%$ and $30 \%$, due to the required initial investment.

Alberto Ramos, assistant director of Development Projects of the CFE, pointed out that the incorporation of renewable energies as substitutes for fossil fuel-generated electricity will be achieved, but over a period of 15 years, according to the international trend.

\section{CURRENT LEGAL FRAMEWORK IN MEXICO}

In renewable energy matters, the main challenge of the government is oriented towards the development of wind energy (Calva, 2007); however, Godoy (2010) and other experts say that these projects are running on such a slow basis, that they are causing disappointment.

According to the Mexican law for the sustainable use of energy (Ley para el Aprovechamiento Sustentable de Energía), published on November 28, 2008, all human and material resources of the National Commission for Energy Conservation (CONAE) are assigned to the newly formed National Commission for Efficient Energy Use (CONUEE). This is an independent agency within the SENER, with technical and operational autonomy intended to promote energy efficiency and its sustainable use.

The SENER and the CRE regulate the operation of the electricity industry, but progress on legislative changes has been slow, which is why the development of alternative energy projects has been postponed.

The electricity sector reform of 1992 opened the door for individuals to generate electricity, whether for self-sufficiency (Telmex, Wal-Mart, PEMEX, Bimbo-Barcel) or within the cogeneration scheme. This legislation created an agreement (Contrato de Interconexión para Fuentes de Energía Renovable - CIFER) which regulates the interconnection rules of renewable resources to the national grid. In January 2005 the Mexican Wind Energy Association (AMDEE) was created, as a civil non-profit and non-governmental organization aimed to promote of the use of wind energy in Mexico.

In terms of financing, the Inter-American Development Bank (IDB) planned, in 2010, to grant about five billion dollars to four wind projects in Mexico in the following years.

Companies and analysts believe that under the current legal framework it is difficult for the private sector to detonate his participation in the goal of $35 \%$ renewable electricity generation by the year 2024 (Saxe-Fernandez, 2009).

Antonio Noyola who serves as Director of Energy Planning for Cemex, talked to the Director of the Presidential Advisors and said: To meet the challenge posed by President Felipe Calderon in renewable energy matters, structural, regulatory, and even constitutional changes are required to trigger the desired level of private sector participation. 
Changes are required to more than 46 different laws to develop a Global Climate Change Act including all sectors. It is essential to reform the law of public service of electricity to allow renewable energies to compete with other fossil technologies and help reduce fossil fuel consumption for electricity generation. If nothing changes in the constitutional mandate that dictates the CFE to purchase electricity at the cheapest cost, then there would be no way renewable energies can have the desired attention in Mexico (Wionczek, 1983).

Antonio Noyola continued explaining: To reach a goal of 10,000 megawatts of renewable energy generation from the private sector, changes are required in legislation, regulatory framework, and even in the way of preparing the projects. He specifically listed the following key points in the process that are time-consuming to investors:

- $\quad$ Checking with the CFE to identify if there is any interconnection capacity.

- $\quad$ The company must personally meet with the Mayor of the place where the project will be established.

- $\quad$ The investor also has to speak with respective state authorities.

- $\quad$ The investor has to talk to the Mexican Ministry of Environment and Natural Resources (SEMARNAT).

- $\quad$ The size of the project is important, because small scale projects are more difficult to be executed.

We need a clearer definition, Noyola said. If the goal for clean energy is $35 \%$ of the total, but it includes wind, solar, hydro, nuclear, geothermal, etc., there could be a risk that nothing would be done based on a vague definition. The law does not specify if there will be a ranking of priorities in order to choose from the available clean energy projects.

If the new law for the efficient use of renewable energy forces the CFE to incorporate electricity from both renewable resources and from fossil fuels in the national grid, it will face a serious dilemma. For example, if it should prioritize energy from a wind farm in Oaxaca, it faces the uncertainty that this electricity is unreliable and pricier, which is against the principles of the CFE in accordance with the provisions of the law of public service of electricity: by economic policy, the CFE should always use the cheapest energy available. The Director of the Presidential Advisors thought: So, are these 2 laws contradicting each other? Definitely, the legal framework should be revised so that it contributes with the generation of electricity that is cheap, reliable, and ecological at the same time. This will not be an easy task, indeed.

\section{REPORTING TO THE PRESIDENT}

Before he started writing his report, the Director of the Presidential Advisors receives an unexpected call from Jean-Luc Vieux-Pernon, Vice-president of Energy of Schneider Electric Mexico who commented: "Mexico will not meet the goal of reducing by $20 \%$ greenhouse gas emissions in 2020 by building clean power generation plants, which is why we should bet for energy efficiency programs to reduce and improve its use." Indeed, according to Arzate (2010), Jean-Luc considered that Mexico raised two ambitious and aggressive, yet difficult goals to achieve, like reducing the emission of greenhouse gases (GHG) - Climate Change Program and increase to 35\% clean energy generation by 2024-National Energy Strategy.

Jean-Luc continued: "The wind, solar, and geothermal projects will be insufficient to achieve the target for Mexico; wind and hydroelectric projects have encountered social barriers and opposition from some communities surrounding the projects, where fights have been strong. Besides, there are economic factors that delay the development of clean energy generation projects, because in some cases the purchase price per kilowatt/hour set by the CFE does not justify the investment or generate adequate investment returns to private producers. Even though there are projects for the production of clean energy, they're moving at a speed that will not allow the country to meet the percentage of clean energy they want, which consists in adding between $5000 \mathrm{Mw}$ and $6000 \mathrm{Mw}$. It's a pretty strong challenge."

While carefully listening on the phone, Mr. Jean-Luc Vieux-Pernon insisted that the development of electricity generation through solar, geothermal, wind, and hydroelectric energy are insufficient to meet the target that was set; hence, the need for the country to analyze the viable option of constructing more nuclear power plants in addition to the one in Laguna Verde, Veracruz, Mexico. "I would like to remind you that $80 \%$ of the energy used 
by France comes from nuclear resources as well as $40 \%$ in Japan, while Mexico only uses less than 5\%." His voice faltered, "However, even if Mexico decided to launch a nuclear power program, it would be impossible to start a new plant of this nature before 2023 or 2025, for which I suggest an additional way to meet these ambitious and complicated objectives of both increasing clean energy use and decreasing GHG emissions to help reduce the impact of climate change: the adoption of systems and habits for the rational use of energy."

By the end of his call, he hung up the phone with great disappointment, and after analyzing all available information, the Director of the Presidential Advisors finds himself in a serious dilemma. What will I report to the President?; Will I have to tell him that his goals to advance in renewable energies are adequate or too optimistic?; Will I have to recommend that we go back to support electricity generated through natural gas combined cycle plants?; Would it be better to shift natural gas consumption, which is facing scarcity in Mexico, and encourage the use of renewable energy?; Should we seek to promote the use of technologies that allow the use of clean fossil fuels?; Have we stayed behind in the development of nuclear energy?; Would it be possible to support the goals of the President by adopting systems and habits for the rational use of energy?; What should I recommend on the development of wind farms in Mexico?; Should I suggest the development of a policy to promote aggressive and concrete renewable energy goals using wind energy for electricity generation and adjustments to the transmission networks in the medium term?; Should we focus only on the development of onshore wind farms, or should we also take advantage of the sea breeze and promote offshore wind farms?; How could we finance the required energy infrastructure: modern, integrated and enduring energy networks?; Should the government allocate a part of its budget to subsidize wind power in Mexico with a long-term vision?; Should we promote the private sector to generate renewable energy?; How could we ensure access to high quality energy resources to the poorest communities?; What would be the best way to avoid $\mathrm{CO}_{2}$ emissions in Mexico?; Should the energy matrix be diversified by using renewable energy resources?; Are the members of the private sector right about these dilemmas?; How could we find electricity rates that make labor-generating companies competitive while meeting the reduction commitments of greenhouse gases in Mexico?

All these dilemmas troubled the Director of the Presidential Advisor's mind. But what he could not clarify in his mind was the way to solve the entrepreneurial dilemma in Mexico. He thought how could it be possible that the U.S. and China - the two countries that emit more than half of the world's greenhouse gas emissions-are the countries that mostly refuse to offer concrete commitments to reduce greenhouse gas emissions. In the negotiations of the $16^{\text {th }}$ Conference of the Parties for Climate Change (COP16) held in Cancun, Mexico from November 29 to December 10, 2010, it was disturbing to see how China - the Asian giant - defended their position claiming that the emission reduction targets should not slow down their economic growth (Villarino, 2010). Wasn't this allegation the same thing that Mexican entrepreneurs asked from President Felipe Calderon?

The future of the electricity industry in Mexico is full of difficulties and challenges. These difficulties can only be overcome with ethical decisions and social responsibility. And the challenges shall be faced considering the technological findings and the involved costs.

\section{AUTHOR INFORMATION}

Flory Anette Dieck-Assad, Ph.D. in Finance from Tulane University (2003). McGraw-Hill published her first textbook Financial Institutions (2004) with a $2^{\text {nd }}$ edition in 2014 used by all the universities of the country. Invited lecturer in Mexico, Chile, U.S.A., Canada, and Europe, got the "Best Lecture Award" in 2004, 2008, 2010, 2011, 2012, and 2013. She has more than 100 publications in national/international magazines, reviews, and journals. She got the "Prize to Education and Research 2007, 2010, and 2014." Texas A\&M University Press published her second book: Energy and Sustainable Development in Mexico (2008), honored with the "National Romulo Garza Award for the Best Written Book". She is Member of the Mexican National System of Researchers (SNI) from December 2005 to date. She became Tenured Professor at Tecnológico de Monterrey in 2011. E-mail: fdieck@itesm.mx 


\section{REFERENCES}

1. Arzate, E. (2010, November 16). México debe mejorar el uso de su energía. El Financiero.

2. Byrne, B. W., \& Houlsby, G. T. (2003). Foundations for offshore wind turbines. Philosophical Transactions of the Royal Society A: Mathematical, Physical, and Engineering Sciences, 361(1813), 29092930.

3. Calva, J. L. (2007). Política energética, agenda para el desarrollo, volumen 8. México: Cámara de Diputados LX Legislatura, Miguel Ángel Porrúa, and UNAM.

4. Chazan, G. (2010, April 22). Una dosis de escepticismo le baja la temperatura a la fiebre de energía eólica. The Wall Street Journal Americas.

5. $\quad$ Comisión Federal de Electricidad - CFE. (2010). Programa de obras del sector eléctrico (POISE) 20102024. México: CFE.

6. CRE - Comisión Reguladora de Energía. (2010). Reportes del Sector Eléctrico.

7. $\quad$ Energy Information Administration (2010). Electric Power Monthly. U.S.A.

8. Galbraith, K. (2009, February 28). Negro panorama para la energía verde. The New York Times.

9. Godoy, E. (2010). Al compás de un viento lento. Petróleo \& Energía, 7(44), 38-40.

10. International Energy Agency_-IEA. (2010). World energy outlook. U.S.A.

11. Keel, M., Kilk, K., \& Valdma, M. (2009). Analysis of power demand and wind power: Changes in power systems. Oil Shale, 26(3), 228-242.

12. López, M. (2010, September 30). Critica Calderón "paradoja” de inversión privada regia. El Norte, p. 1.

13. Makkawi, A., Celik, A., \& Muneer, T. (2009). Evaluation of micro-wind turbine aerodynamics, wind speed sampling interval and its spatial variation. Building Services Engineering Research and Technology, 30(1), 7-14.

14. Revkin, A. C. (2006, November 4). Para salvar al mundo y a nosotros. Mundo en calentamiento necesita ideas y dinero. The New York Times.

15. Rosenthal, E. (2010, October 30). Pueblo italiano va viento en popa. The New York Times, p. Negocios.

16. Saxe-Fernandez, J. (2009). La energía en México: Situación y alternativas. México: Centro de Investigaciones Interdisciplinarias en Ciencias y Humanidades, Universidad Nacional Autónoma de México (UNAM).

17. SENER-Secretaría de Energía. (2010). Estrategia Nacional de Energía en México. México, D.F.: SENER.

18. Villarino, A. (2010, November 26). Cop 16: Exige Beijing sacrificios por clima a desarrollados. Urge China a E.U. a dar primer paso. El Norte; Sección Internacional, p. 24.

19. Wionczek, M. S. (1983). Problemas del sector energético en México. México: El Colegio de México. 


\section{NOTES}

